\title{
Corrosion Behaviour of AZ and ZA Magnesium Alloys in Alkaline Chloride Media
}

\author{
Mustafa Ö. Öteyaka, ${ }^{1}$ Edward Ghali, ${ }^{2}$ and Réal Tremblay ${ }^{2}$ \\ ${ }^{1}$ Department of Mechanical Engineering, Dumlupinar University, 43100 Kütahya, Turkey \\ ${ }^{2}$ Department of Mining, Metallurgical and Materials Engineering, Laval University, Quebec City, QC, Canada G1V $0 A 6$
}

Correspondence should be addressed to Edward Ghali, edward.ghali@gmn.ulaval.ca

Received 16 August 2012; Revised 2 November 2012; Accepted 5 November 2012

Academic Editor: Chang-Jian Lin

Copyright ( $\odot 2012$ Mustafa Ö. Öteyaka et al. This is an open access article distributed under the Creative Commons Attribution License, which permits unrestricted use, distribution, and reproduction in any medium, provided the original work is properly cited.

Corrosion behaviour of AZ and ZA magnesium alloys in untreated, aerated, and deaerated chloride media was investigated. The influence of impurity, alloying element, and oxygen on corrosion potential, rate, and pitting was examined in alkaline media saturated with $\mathrm{Mg}(\mathrm{OH})_{2}$ at $\mathrm{pH} 9$ and $25^{\circ} \mathrm{C}$. After $8 \mathrm{~h}$ immersion, slightly less active corrosion potentials were generally observed in deaerated than oxygen containing solutions. AZ91D and ZA104 alloys recorded much lower corrosion rates in deaerated medium as compared to AZ91E, ZAC 10403 (0.3Ca), and ZACS1040305 (0.3Ca+ 0.5Sr). Generally, ZAC alloy showed the highest corrosion rate, followed by ZACS alloy, and both showed a constant value in the three media with or without oxygen. The effect of oxygen is then dependent on the alloy properties and is not a simple acceleration of the cathodic reaction but could cause also inhibition and/or passivation. Pit depth and distribution were influenced by alloy composition. The pits were found deeper and more localized on AZ and more uniformly dispersed on ZA alloy surfaces.

\section{Introduction}

Magnesium, as a structural material, has numerous advantages with regard to aluminum (lighter by almost 36\%) and plastics (almost the same specific density) [1,2]. Magnesium alloys, in particular those with aluminum (Al) and $\mathrm{Zinc}(\mathrm{Zn})$ as alloying elements, are frequently exposed to degradation caused by corrosion.

The poor corrosion resistance of many magnesium alloys may be the result of internal galvanic corrosion caused by second phases or impurities. It is well documented that the presence of noble metal impurities $(\mathrm{Fe}, \mathrm{Ni}$, and $\mathrm{Cu}$ ) represents the most detrimental factor influencing the corrosion properties of commercial magnesium alloys [3]. Magnesium suffers pitting when exposed to chloride solutions in nonoxidizing media at open circuit potential. In solutions containing 10 and $1000 \mathrm{ppm}$ of $\mathrm{NaCl}$, the $\mathrm{Mg}$ corrosion potential is -1060 and $-1310 \mathrm{mV}$ versus SHE, respectively [4]. Wilde and Williams [5] measured the corrosion potential changes with time of some corrosion resistant alloys during pitting and found that the corrosion potential decreased in all the alloys when the corrosion potential exceeded the pitting potential. Studies on pitting phenomena on $\mathrm{Mg}$ and $\mathrm{Mg}$ alloys have compared the pitting behaviour of die-cast alloys and rapidly solidified (thixomolded) Mg alloys [6-9]. For example, the good pitting resistance of die-cast $\mathrm{AE}$ alloys was attributed to the presence of Al-rich zones which appeared to act as barrier against pit propagation.

Makar and Kruger [10] showed that rapidly solidified AZ61 alloy exhibited a breakdown potential $200 \mathrm{mV}$ higher than that of cast AZ61 alloy in buffered carbonate solution ( $\mathrm{pH}$ 10) containing various levels of $\mathrm{Cl}^{-}$. The surface layer was also composed primarily of $\left(\mathrm{MgO} \cdot \mathrm{H}_{2} \mathrm{O}\right)$. The morphology and structure of oxide films on magnesium, formed in air and water, were also shown to be formed by a three-layer system consisting of an inner cellular structure $(0.4-0.6 \mathrm{~mm})$, a dense intermediate regime $(20-40 \mathrm{~nm})$, and an outer layer with a platelet-like morphology (approximately $2 \mathrm{~mm}$ ) [11]. Baril and Pébère [12] studied the corrosion behaviour of pure magnesium in aerated and deaerated sodium sulphate solutions $(0.01$ and $0.1 \mathrm{M})$ by steady-state current-voltage and electrochemical impedance measurements. It was shown that the anodic current densities were lower and the corrosion resistance values were higher in deaerated media. They 
concluded that the presence of oxygen did not influence the corrosion of pure magnesium and showed that the corrosion rate was dependent on $\mathrm{HCO}_{3}{ }^{-}$concentration in the solution.

AZ91 (Mg-9Al-1Zn) alloy is by far the most commonly used magnesium cast material. The popularity of this particular alloy is a result of its good corrosion resistance as well as favourable castability and mechanical properties [13-15]. AZ91 alloy has a two-phase microstructure typically consisting of a matrix of $\alpha$-Mg grains with an intermetallic $\beta$-phase $\left(\mathrm{Mg}_{17} \mathrm{Al}_{12}\right)$ along the grain boundaries [16]. The physical significance of aluminum as the alloying element is largely related to an increased passivity of the oxide film formed on the surface [17]. However, it seems that a threshold of $4 \% \mathrm{Al}$ in the alloy is required. Precipitation of the more corrosionresistant $\mathrm{Mg}_{17} \mathrm{Al}_{12}$ ( $\beta$-phase), which acts as a corrosion barrier, has also been claimed to improve corrosion [13]. Furthermore, it was reported that the corrosion potential of $\beta$-phase in $5 \% \mathrm{NaCl}$ saturated solution with $\mathrm{Mg}(\mathrm{OH})_{2}$ was approximately 490 and $420 \mathrm{mV}$ more cathodic to pure $\mathrm{Mg}$ and AZ91 alloy, respectively [13]. The solubility of rare earths (RE) in the magnesium matrix is very limited in the presence of aluminum, but the intermetallic Al-RE formed is electrochemically passive and does not significantly affect the corrosion rate [18].

Alloying elements such as strontium (Sr) and calcium (Ca) can be chosen to improve magnesium alloy performance in order to be used for structural applications in aggressive environments. Considering the electrochemical potential values, the addition of $\mathrm{Ca}$ should result in low microgalvanic effects. Reduction of the anodically active area upon precipitation was reported for $\mathrm{Mg}-\mathrm{Ca}-\mathrm{Cu}$ splats where precipitation of $\mathrm{Mg}_{2} \mathrm{Ca}$ neutralises the galvanic effect produced by the $\mathrm{Mg}_{2} \mathrm{Cu}$ phase. The addition of $2 \% \mathrm{Ca}$ decreased the corrosion rate of rapid solidified AZ91 alloy from 0.8 to $0.2 \mathrm{~mm} /$ year [19]. Furthermore, AZ91 castings with $0.3 \% \mathrm{Sr}$ alloy displayed considerably reduced microporosity with no significant loss in strength and ductility at room temperature [20].

AZ alloys are used extensively in many commercial applications and ZA alloys are less expensive and still emerging. Previous studies have examined the corrosion behaviour of these two different categories of magnesium alloys (AZ and ZA) in various solutions [21-24]. It was concluded that pitting corrosion was an important and prevalent form of degradation of these alloys. It was also demonstrated that the pits were more numerous on the surface of ZACS1040305 (Mg-10Zn-4Al-0.3Ca-0.5Sr) alloy than on that of AZ91E alloy. Moreover, uniform corrosion was observed on ZAC10403 (Mg-10Zn-4Al-0.3Ca) and ZACS1040305 alloys, while pitting corrosion was present on AZ91E alloy in 5\% NaCl solution saturated with atmospheric oxygen at $25^{\circ} \mathrm{C}$, with $\mathrm{Mg}(\mathrm{OH})_{2}$ at $\mathrm{pH} 9$.

As the primary alloying element in $\mathrm{AZ}$ magnesium alloys is aluminum, while that in ZA alloys is zinc, this major difference could affect their corrosion behaviour in untreated, aerated, and deaerated chloride medium. To our knowledge the corrosion behaviour of AZ and ZA alloys in such solutions containing different contents in oxygen has never been investigated. The objectives of the present study were to examine and compare, using conventional techniques, the corrosion characteristics and particularly the pitting behaviour of these two groups of magnesium alloys (AZ and ZA) in untreated, aerated, and deaerated alkaline $5 \% \mathrm{NaCl}$ solution.

\section{Experimental Procedure}

2.1. Material and Sample Preparation. In accordance with ASTM standard B93/B93M-09 [25], permanent mold castings were produced from five different alloys: AZ91D, AZ91E, ZA104, ZAC10403, and ZACS1040305. Table 1 presents the chemical composition of these alloys. Corrosion test samples of $1 \times 1 \times 2 \mathrm{~cm}$ were taken from the castings and encased in epoxy resin. Each sample was then polished with 600 and 1200 grit $\mathrm{SiC}$ papers and 3 micron diamond paste, cleaned with alcohol, dried, and subsequently exposed to the test solution.

2.2. Electrochemical Technique. The free corrosion potential $\left(E_{\text {corr }}\right)$ and potentiodynamic curves of magnesium alloys AZ91D, AZ91E, ZA104, ZAC10403, and ZACS1040305 were determined in the following aqueous media: untreated, aerated, and deaerated $5 \% \mathrm{NaCl}$ solutions saturated with $\mathrm{Mg}(\mathrm{OH})_{2}$ at $\mathrm{pH} 9$ and $25^{\circ} \mathrm{C}$, using a Model 273 potentiostat/galvanostat (EG\&G). ASTM standard G5-94 [26] was used to perform the potentiodynamic tests. Following immersion in the solution, the test began within one minute. The open circuit potential (OCP or $E_{\text {corr }}$ ) measurement was performed for a period of $8 \mathrm{~h}$. Potentiodynamic curves were traced at a scanning rate of $0.1 \mathrm{mV} \cdot \mathrm{s}^{-1}$ on the polished surfaces over a potential range of $1000 \mathrm{mV}$ (cathodic polarisation $-10 \mathrm{mV}$ versus corrosion potential). All of the potentials are given with respect to a saturated calomel reference electrode $\mathrm{Hg} / \mathrm{Hg}_{2} \mathrm{Cl}_{2 \text { (solid) }} / \mathrm{KCl}_{\text {sat. }}(0.242 \mathrm{~V}$ versus $\mathrm{SHE}$ ). Experimental corrosive media were obtained as follows: the untreated $5 \% \mathrm{NaCl}$ solution corresponded to air saturation with oxygen $\left(\approx 5.8 \mathrm{~mL} \cdot \mathrm{L}^{-1}\right.$ of dissolved oxygen $)$, the aerated $5 \% \mathrm{NaCl}$ solution was completely saturated with air bubbling $\left(\approx 12.5 \mathrm{~mL} \cdot \mathrm{L}^{-1}\right.$ of dissolved oxygen [27]), and the deaerated $5 \% \mathrm{NaCl}$ solution was obtained by nitrogen bubbling to eliminate dissolved oxygen. At least three tests were performed under each condition. The reproducibility of corrosion rate was of the order of $\pm 5-10 \%$.

2.3. Surface Observations. Following $8 \mathrm{~h}$ of immersion, the specimens were examined under an optical microscope (OM) equipped with an image analyser to characterise the corroded surface. Surface topography was investigated using an atomic force microscope (AFM) in the tapping mode. Images were taken with $5000 \times 5000$ data acquisition at a scan rate of $1 \mathrm{~Hz}$ in air at room temperature. Tridimensional surface topography was mapped for an area of $50 \times 50 \mu \mathrm{m}$ using the integrated software program.

\section{Results and Discussion}

3.1. Corrosion Potential Analysis. Figure 1 shows the time variations of $E_{\text {corr }}$ for AZ91D and AZ91E alloys during $8 \mathrm{~h}$ of immersion in the untreated, aerated, and deaerated 
TABLE 1: Chemical composition (wt $\%)^{*}$ of the magnesium alloys used.

\begin{tabular}{lccccccccccc}
\hline Alloy & $\mathrm{Al}$ & $\mathrm{Zn}$ & $\mathrm{Ca}$ & $\mathrm{Sr}$ & $\mathrm{Mn}$ & $\mathrm{Si}$ & $\mathrm{Fe}$ & $\mathrm{Cu}$ & $\mathrm{Ni}$ & $\mathrm{Mg}$ \\
\hline AZ91D & 9.00 & 0.67 & - & - & 0.33 & 0.010 & 0.005 & 0.030 & 0.002 & $\mathrm{Bal}$ \\
AZ91E & 8.70 & 0.70 & - & - & 0.26 & 0.200 & 0.005 & 0.015 & 0.001 & Bal. \\
ZA104 & 3.69 & 9.73 & - & - & 0.25 & 0.015 & 0.030 & $<0.001$ & 0.001 & Bal. \\
ZAC10403 & 3.78 & 10.5 & 0.31 & - & 0.03 & 0.001 & 0.003 & $<0.001$ & 0.002 & Bal. \\
ZACS1040305 & 4.12 & 11.7 & 0.31 & 0.54 & 0.35 & $18 \mathrm{ppm}$ & $189 \mathrm{ppm}$ & $2 \mathrm{ppm}$ & $2 \mathrm{ppm}$ & Bal. \\
\hline
\end{tabular}

*Throughout the text, the percentage of elements and solution concentration is expressed in weight percent.

$5 \% \mathrm{NaCl}$ solutions saturated with $\mathrm{Mg}(\mathrm{OH})_{2}$. For AZ91D, the $E_{\text {corr }}$ value increases somewhat during the first $30 \mathrm{~min}$ and remained stable thereafter, showing a slight rise in the untreated and deaerated solutions (Figure 1(a)). This behaviour may reflect several phenomena called constant process of breakdown and repair of passivation: film initiation, attack by the $\mathrm{Cl}^{-}$ion, and possibly formation of protective corrosion products on the surface. Moreover, the average corrosion potential values in the aerated solution were generally similar to those obtained in the untreated solution. The $E_{\text {corr }}$ values of AZ91D in the aerated solution increased suddenly after $3 \mathrm{~h}$ immersion, indicating a possible slowing down of the corrosion reaction. A possible explanation for this behaviour may be the presence of oxygen which may have accelerated the production of corrosion products on the surface of AZ91D specimen as compared to the untreated solution.

Figure 1(b) presents the variation of $E_{\text {corr }}$ over time for the AZ91E alloy in the untreated, aerated, and deaerated $5 \% \mathrm{NaCl}$ solutions saturated with $\mathrm{Mg}(\mathrm{OH})_{2}$. In the first $30 \mathrm{~min}$ of immersion, a rapid drop of potential was observed toward more negative values in all three corrosive media. During the rest of the immersion period, the $E_{\text {corr }}$ of AZ91E in the untreated and aerated solutions remained relatively stable, with a significant difference of $\approx 20 \mathrm{mV}$ observed in the deaerated solution, which can suggest an important corrosion rate.

Figure 2 illustrates the time variation of $E_{\text {corr }}$ for the $\mathrm{ZA}$ alloys in the untreated, aerated, and deaerated 5\% $\mathrm{NaCl}$ solutions saturated with $\mathrm{Mg}(\mathrm{OH})_{2}$. For alloy ZA104 (Figure 2(a)), the $E_{\text {corr }}$ gradually increased during the immersion period in all three corrosive media. However, in the deaerated medium, the corrosion potential remained less negative than that of the other two media throughout the entire testing process. This behaviour may be attributed to a stable growth of the protective surface film. Figure 2(b) shows the effect of adding $0.3 \%$ Ca to ZA104 alloy. The $E_{\text {corr }}$ value for alloy ZAC10403 increased slightly up to $6 \mathrm{~h}$ of immersion and was higher in the aerated and deaerated solutions. For alloy ZACS1040305, containing an additional $0.5 \% \mathrm{Sr}$, the free corrosion potential $\left(E_{\mathrm{corr}}\right)$ remained relatively constant or stationary in the three corrosive media after the first $30 \mathrm{~min}$ of immersion (Figure 2(c)).

Table 2 summarises the average $E_{\text {corr }}$ values obtained for the $\mathrm{AZ}$ and $\mathrm{ZA}$ magnesium alloys after $8 \mathrm{~h}$ of immersion in the untreated, aerated, and deaerated $5 \% \mathrm{NaCl}$ solutions saturated with $\mathrm{Mg}(\mathrm{OH})_{2}$. As determined from the free corrosion measurements, the corrosion potential values were shown to be relatively close to one another or in the same zone of potential values independent of oxygen content in the solutions. Baril and Pébère [12] have already stated that oxygen did not play a major role in the corrosion potential of pure magnesium. The present results support the same statement for the AZ and ZA groups of alloys. However, in comparing the corrosion potential of AZ91E alloy with that of the other alloys, and based on several measurements, it can be statistically confirmed that the purity of the alloy showed a trend toward more active potentials (Table 2).

More specifically, it can be stated that the active $E_{\text {corr }}$ of AZ91E was $\approx 10-30 \mathrm{mV}$ more negative than that of AZ91D in the examined three corrosive media. This may be explained by the low impurity content of the AZ91E alloy. The corrosion potential observed for ZA104 was more positive $(\approx 20 \mathrm{mV})$ in the deaerated solution than in the oxygen containing solutions, likely due in part to the presence of an active aluminum phase. For ZAC10403 alloy, the increase towards less negative values of corrosion potential observed after $6 \mathrm{~h}$ of immersion in the aerated solution (Figure 2(b)) was most likely resulting from two events, namely, the initiation or formation of oxide layer (including $\mathrm{CaO}$ ) and the probable obstruction of corrosion product on the surface. The recorded corrosion potentials of alloy ZACS1040305 appear to be similar to ZAC alloy regardless of the media used (Figure 2(c)). After $8 \mathrm{~h}$ of immersion in deaerated solution, the $E_{\text {corr }}$ values for ZAC and ZACS alloys (Table 2) indicate the same results despite probable different corrosion rates related to various chemical compositions and microstructures [22].

3.2. Potentiodynamic Study. Figure 3 shows the potentiodynamic curves of the $\mathrm{AZ}$ and $\mathrm{ZA}$ magnesium alloys in the untreated, aerated, and deaerated $5 \% \mathrm{NaCl}$ solutions saturated with $\mathrm{Mg}(\mathrm{OH})_{2}$ at $\mathrm{pH}$ 9. With one exception, it can be generally stated from the potentiodynamic curves that the presence of dissolved oxygen in different quantities had minor influence on the form of the cathodic polarisation curve and consequently no significant effect on the corrosion rates of the studied alloys. There was no one standard or conventional cathodic polarisation curve that obeys Tafel law and could lead us to determine corrosion rate with great precision. It is nevertheless clear that the corrosion behaviour of these alloys is particularly complex in these three passive chloride alkaline media; the term passive referring to the theoretical approach put forth by the Pourbaix E-pH diagram.

In previous studies [21-23], a passive zone was observed in alloys ZA104 and ZAC10403 in untreated 5\% $\mathrm{NaCl}$ 


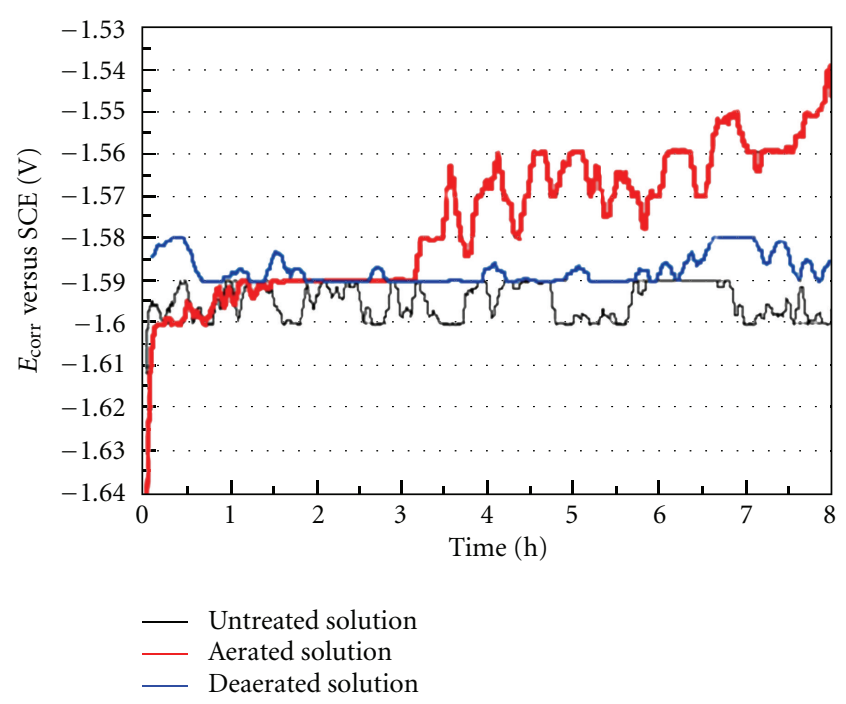

(a)

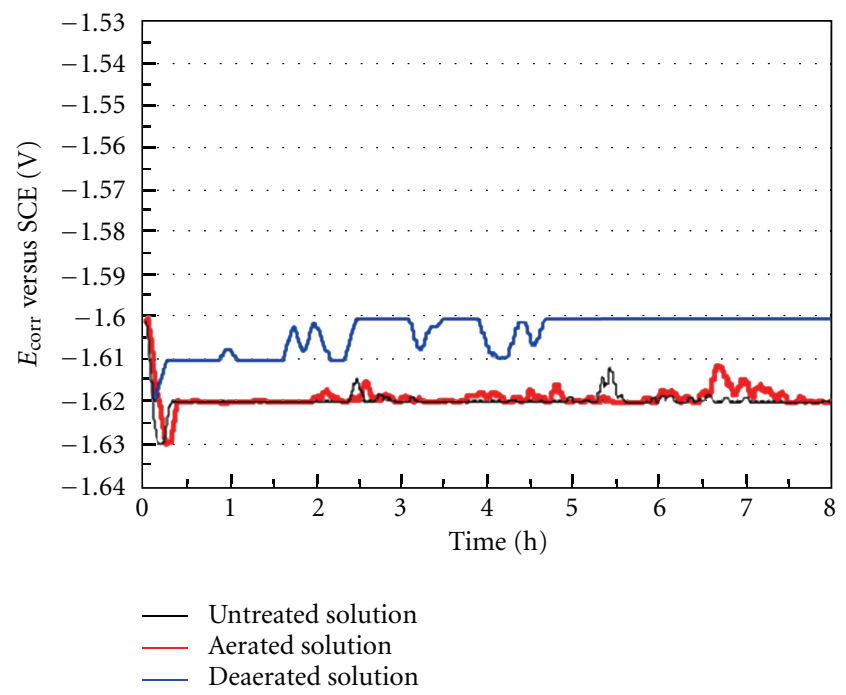

(b)

Figure 1: Time variation of $E_{\text {corr }}$ for (a) AZ91D and (b) AZ91E in untreated, aerated, and deaerated $5 \% \mathrm{NaCl}$ solution saturated with $\mathrm{Mg}(\mathrm{OH})_{2}$ at $\mathrm{pH} 9$ and $25^{\circ} \mathrm{C}$.

solution saturated with $\mathrm{Mg}(\mathrm{OH})_{2}$ at $\mathrm{pH}$ 9. In this study, a passive zone was monitored for alloy ZAC10403 in aerated and deaerated solutions. This passive zone can be associated with the sudden observed increase of Ecorr after $6 \mathrm{~h}$ of immersion (Figure 2(b)).

In yet another study [24], using different electrochemical techniques with ZA alloy compositions for long immersion periods in aerated and deaerated $5 \% \mathrm{NaCl}$ solutions with the same hydroxide saturation and $\mathrm{pH}$, it was concluded that the corrosion resistance or passivation was better with the addition of $\mathrm{Sr}$ associated with $\mathrm{Ca}$ than with the addition of Ca alone.

3.3. Corrosion Rates. Results reported in Table 3 show that in the untreated solution alloy AZ91E recorded the lowest
TABLE 2: Average $E_{\text {corr }}$ values (V) for AZ and ZA magnesium alloys after $8 \mathrm{~h}$ of immersion in deaerated, untreated and aerated $5 \% \mathrm{NaCl}$ solutions saturated with $\mathrm{Mg}(\mathrm{OH})_{2}$ at $\mathrm{pH} 9$ and $25^{\circ} \mathrm{C}$. (Standard deviation $<10 \mathrm{mV}$ ).

\begin{tabular}{lccc}
\hline Alloys & $\begin{array}{c}\text { Deaerated } \\
\text { solution }\end{array}$ & $\begin{array}{c}\text { Untreated } \\
\text { solution }\end{array}$ & $\begin{array}{c}\text { Aerated } \\
\text { solution }\end{array}$ \\
\hline AZ91D & -1.587 & -1.593 & -1.550 \\
AZ91E & -1.600 & -1.620 & -1.618 \\
ZA104 & -1.546 & -1.562 & -1.565 \\
ZAC10403 & -1.560 & -1.562 & -1.562 \\
ZACS1040305 & -1.581 & -1.600 & -1.586 \\
\hline
\end{tabular}

corrosion current rate as earlier reported in [28], with higher but equal values for alloys AZ91D and ZA104, followed by ZACS1040305, and finally ZAC10403, with the highest corrosion rate. Concerning AZ91E, this result confirms the fact that it had better corrosion resistance over AZ91D. It is also well documented that the presence of more noble metal impurities such $\mathrm{Cu}, \mathrm{Ni}$, and $\mathrm{Fe}$ in AZ91D is the most detrimental factor influencing the corrosion properties of alloys in this solution [3,4]. The corrosion rates of ZAC10403 and ZACS1040305 were twice or more than those of AZ91E in the untreated solution. It can thus be stated that the superior performance of alloy AZ91E was due to the formation of magnesium hydroxide at the surface, which halted the progression of dissolution. The relative poor performance of ZA to AZ91E was most likely due to the galvanic effect of intermetallic $\mathrm{Mg}_{x} \mathrm{Zn}_{y} \mathrm{Al}_{z}$ with the magnesium matrix.

For a finely polished surface of ZAC alloy specimens tested in the three examined media, the corrosion rate increased by $40 \%$ to a maximum of $5 \mu \mathrm{A} \cdot \mathrm{cm}^{-2}$ for ZAC10403 due to the addition of calcium and by $20 \%$ to a value of $4 \mu \mathrm{A} \cdot \mathrm{cm}^{-2}$ for ZACS1040305 due to the presence of (Ca + $\mathrm{Sr}$ ) comparatively to ZA104 (Table 3). Calcium appeared to have a strong accelerating effect due to more active galvanic cells at the corrosion potential, while the presence of $\mathrm{Sr}$ partially inhibited this effect. It is known that strontium acts as a beneficial element by decreasing the corrosion rates and improving the corrosion resistance of $\mathrm{AZ}$ magnesium alloy group in $5 \% \mathrm{NaCl}$ solution saturated with $\mathrm{Mg}(\mathrm{OH})_{2}$ at $\mathrm{pH} 9$ on atmospheric oxygen [22, 24].

As can be seen in Table 3, all the alloys were not really influenced by the quantitative difference in oxygen concentration from atmospheric saturation (untreated solution) to complete saturation by air bubbling (aerated solution). The only exception was alloy AZ91E, where the relatively low quantity of atmospheric oxygen in the solution appeared to have had a favourable passive effect at $\mathrm{pH}$, resulting in the lower corrosion rate. This result can be logically attributed to the composition and microstructure of the alloy.

The deaerated medium appeared to be very beneficial for alloys AZ91D and ZA104 which displayed the lowest corrosion rates (Table 3 ). These two alloys, containing $\mathrm{Zn}$ or impure elements such as $\mathrm{Fe}$ and $\mathrm{Ni}$, were largely influenced by oxygen in serving as cathodes to increase corrosion rate. Baril and Pébère [12] reported that the corrosion potential 


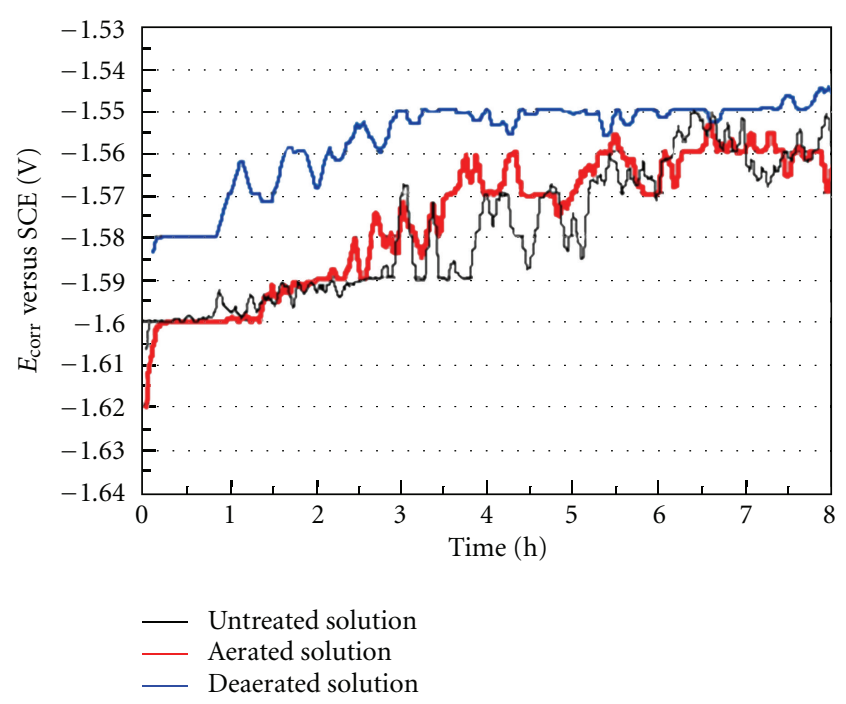

(a)

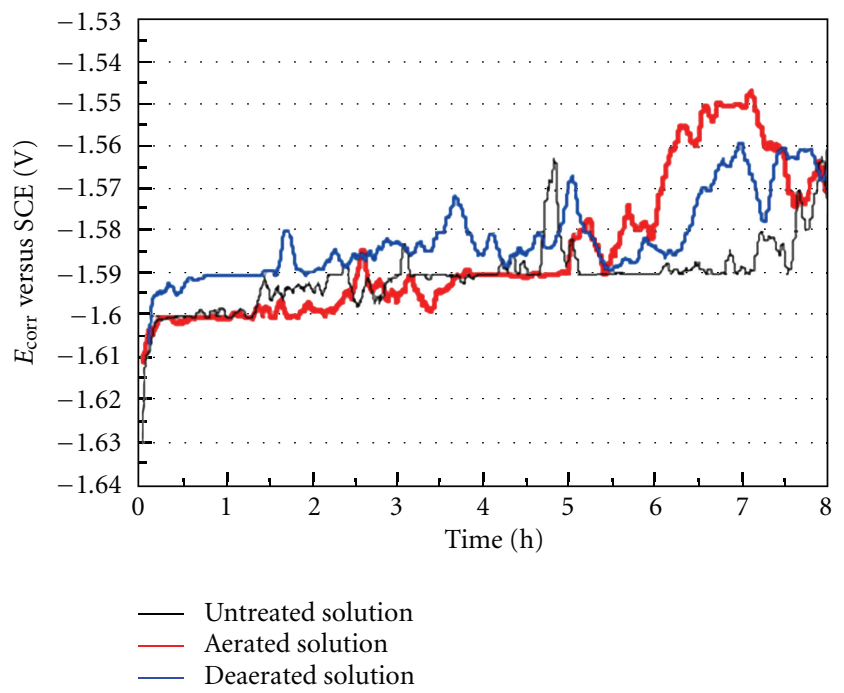

(b)

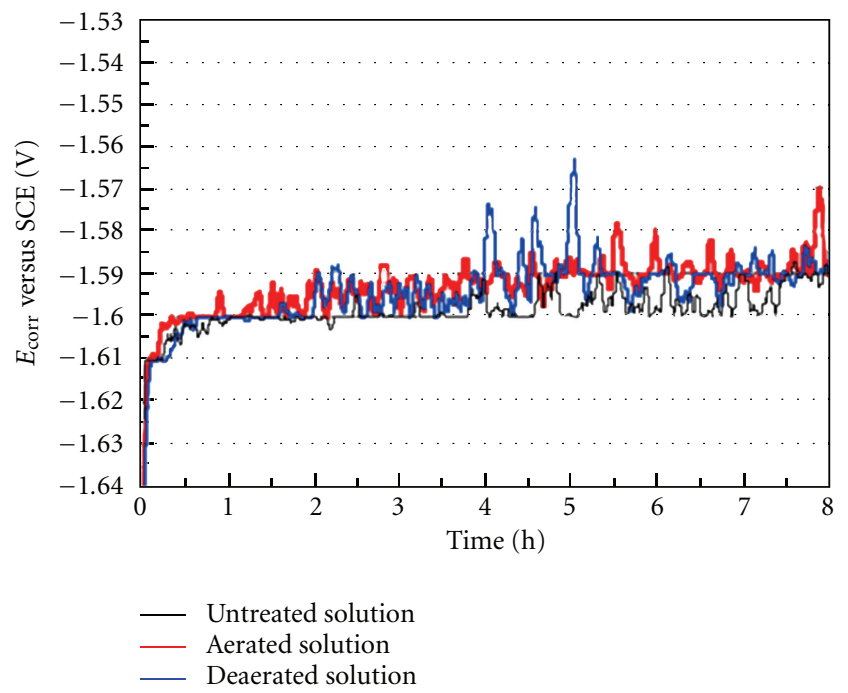

(c)

FIGURE 2: Time variation of $E_{\text {corr }}$ for (a) ZA104, (b) ZAC10403, and (c) ZACS1040305 in untreated, aerated, and deaerated $5 \%$ NaCl solution saturated with $\mathrm{Mg}(\mathrm{OH})_{2}$ at $\mathrm{pH} 9$ and $25^{\circ} \mathrm{C}$.

TABle 3: Approximate $i_{\text {corr }}$ values $\left(\mu \mathrm{A} \cdot \mathrm{cm}^{-2}\right)$ for the $\mathrm{AZ}$ and $\mathrm{ZA}$ magnesium alloys calculated from the potentiodynamic curves by the method of linear polarization.

\begin{tabular}{lcccc}
\hline Alloy & $\begin{array}{c}\text { Deaerated } \\
\text { solution }\end{array}$ & $\begin{array}{c}\text { Untreated } \\
\text { solution }\end{array}$ & $\begin{array}{c}\text { Aerated } \\
\text { solution }\end{array}$ & Model $^{1}$ \\
\hline AZ91D & 2 & 3 & 3 & III \\
AZ91E & 4 & 2 & 3 & IV \\
ZA104 & 2 & 3 & 3 & III \\
ZAC10403 & 5 & 5 & 5 & V \\
ZACS1040305 & 4 & 4 & 4 & V \\
\hline
\end{tabular}

${ }^{1}$ Mechanistic corrosion models are described in Section 3.4.

of pure magnesium (in absence of alloying element) was more active in deaerated $\mathrm{Na}_{2} \mathrm{SO}_{4}$ solution and that the anodic current densities were lower than those found under aerated conditions. In this study, content in impurity and alloying elements in AZ91E alloy seems to act as active cathodes increasing corrosion in deaerated alkaline medium, and causing a corrosion rate twice that of AZ91D and ZA104 alloys in the same solution (Table 3 ). Then, it can be stated that corrosion rate in absence of dissolved oxygen depends mainly on alloy composition and microstructure.

3.4. Interpretations of Oxygen Effect on $E_{\text {corr }}$ and $i_{\text {corr }}$. Some phenomena should be considered for potential values of magnesium alloys in active-passive media. The metal is originally very active and sufficient metallic ions are formed giving nonconductive corrosion products (oxides or hydroxides) on the metallic surface in alkaline medium. Some metallic sites relatively poor in metallic ions could give active potentials for the entire surface. The potentials recorded in this study could reflect the average of both active and passive 


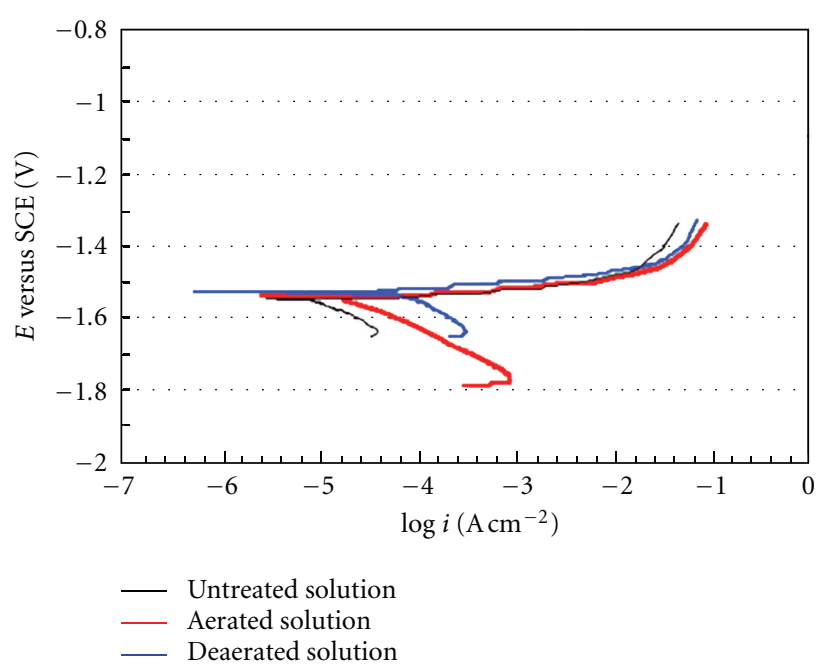

(a)

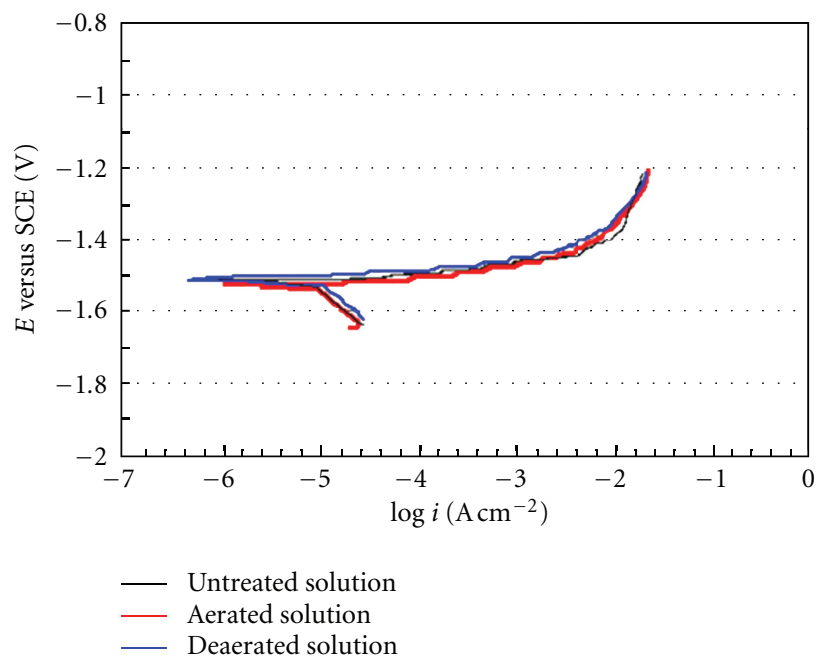

(c)

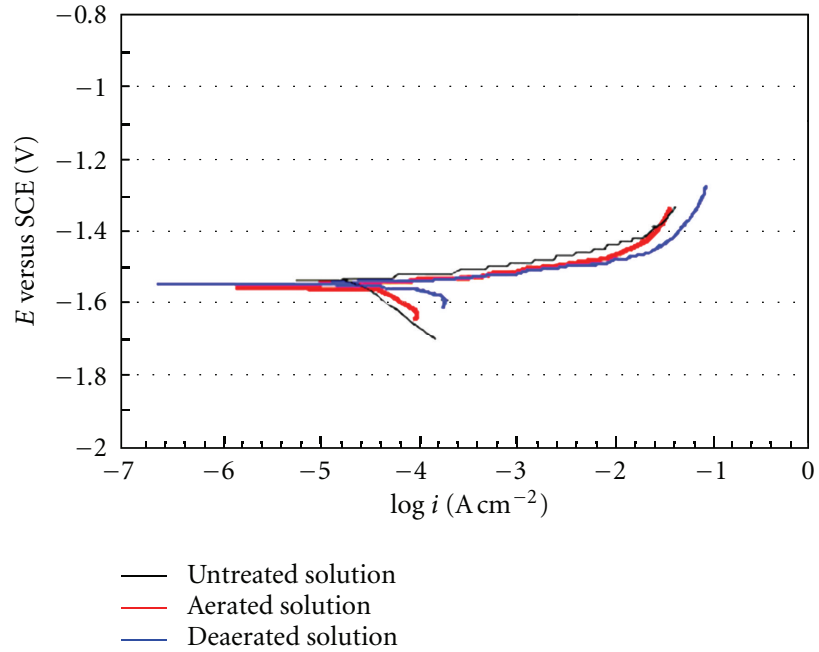

(b)

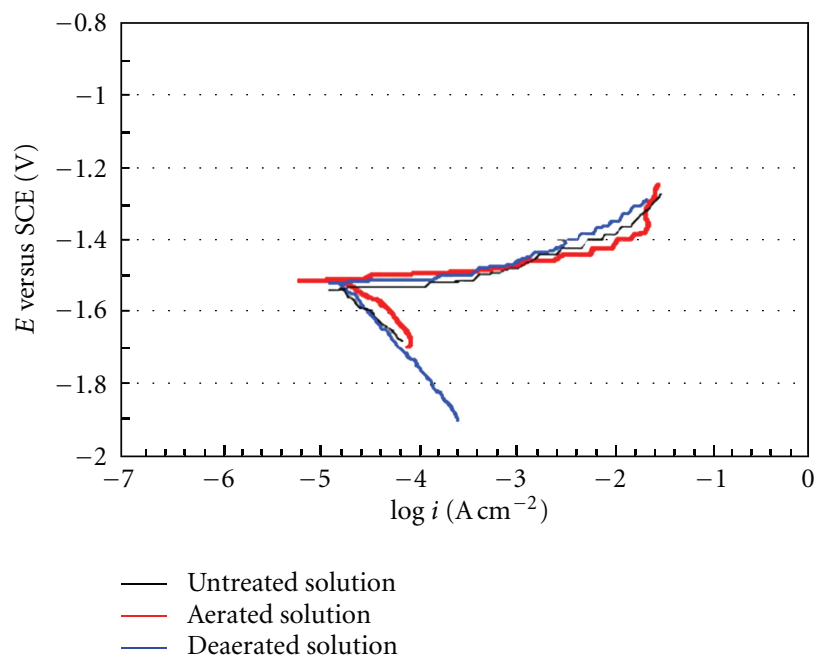

(d)

FIgUre 3: Potentiodynamic curves at a scan rate of $0.1 \mathrm{mV} \cdot \mathrm{s}^{-1}$ for (a) AZ91D, (b) AZ91E, (c) ZA104, and (d) ZAC10403 in untreated, aerated, and deaerated $5 \% \mathrm{NaCl}$ solution saturated with $\mathrm{Mg}(\mathrm{OH})_{2}$ at $\mathrm{pH} 9$ and $25^{\circ} \mathrm{C}$.

regions but very frequently the potential of the active sites dominates. Also, a quantity of other metallic impurities such as $\mathrm{Cu}, \mathrm{Fe}$, and $\mathrm{Ni}$ could cause very efficient galvanic corrosion and polarize the open circuit potential. For example, in case of iron and mild steels, the accelerating effect of oxygen is commonly accompanied by a certain shift to more positive or noble potentials because of the exothermic reaction accompanying the hydrogen reduction in presence of oxygen. Also, principally different corrosion rates could exist for the same potential and generally no relation could be suggested between potential values and corrosion rates in this study [29].

However, it is interesting to compare the variation of corrosion rates of magnesium alloys in the alkaline medium with those of mild steels in neutral water medium since these two types of alloys show similar active-passive behaviours in such media. The effect of oxygen content on corrosion rate of mild steels in water at neutral passive solutions has been extensively examined by Uhlig and Revie [30]. In their study, the effect of oxygen concentration on corrosion rates of mild steels in slightly agitated distilled water during tests of $48 \mathrm{~h}$ at $25^{\circ} \mathrm{C}$ was considered. Three mechanistic corrosion models were illustrated based on the amount of dissolved oxygen in the solution. For low concentration of dissolved oxygen ( 0 to $4 \mathrm{~mL} / \mathrm{L}$ ), acceleration of the cathodic reaction is dominant with increasing oxygen concentration and the corrosion rate increases quasi-linearly (model I). This acceleration is principally due to the depolarization of the cathodic reaction or to replacement of the slow hydrogen evolution by an exothermic cathodic reaction in the presence of oxygen at $25^{\circ} \mathrm{C}$ and atmospheric pressure:

$$
\begin{aligned}
2 \mathrm{H}^{+}+2 \mathrm{e}^{-} \longrightarrow \mathrm{H}_{2} \mathrm{O} & (E=0.00-0.0592 \mathrm{pH}) \mathrm{V} \\
2 \mathrm{H}^{+}+2 \mathrm{e}^{-}+\frac{1}{2} \mathrm{O}_{2} \longrightarrow \mathrm{H}_{2} \quad(E & =1.23-0.0592 \mathrm{pH}) \mathrm{V}
\end{aligned}
$$


The complete and maximum depolarization by oxygen depends on the presence of sufficient oxygen concentration and enough cathodic sites at the interface $\mathrm{Fe}-\mathrm{H}_{2} \mathrm{O}$. For dissolved oxygen concentration between $\approx 5$ to $17 \mathrm{~mL} / \mathrm{L}$, a slowing down of the quasi-linear acceleration of the corrosion rate and the appearance of progressive inhibition-passivation phenomenon at the interface are observed (model (I + II)). This inhibition could be caused by a controlled oxygen quantity at the interface, less cathodic or anodic sites on the specimen due to corrosion product (oxides) or adsorbed oxygen, and the presence of passive layer at the interface. For higher dissolved oxygen concentration $(\approx 18$ to $25 \mathrm{~mL} / \mathrm{L})$, the corrosion rate is dominated by the inhibition-passivation phenomenon and decreases progressively (model II). It is clearly shown that the corrosion rate could return to low values close to that measured in absence of oxygen.

In the present study, the corrosion rates of magnesium alloys reported in Table 3 reveal the presence of three intermediate situations based on the mechanistic corrosion models described previously [31]. Then, for AZ91D and ZA104 alloys, increasing the amount of dissolved oxygen concentration in alkaline chloride media from atmospheric saturation $(5.8 \mathrm{~mL} / \mathrm{L})$ to complete saturation $(12.5 \mathrm{~mL} / \mathrm{L})$ has no influence on the corrosion rate (model III). It could be assumed also that the inhibiting effect of the additional dissolved oxygen eliminated the expected accelerating one.

AZ91E alloy shows a fast corrosion rate which could be related to abundant anodic and cathodic sites in absence of dissolved oxygen (model IV). In this case, atmospheric saturated oxygen is able to imply $50 \%$ inhibition passivation, while higher quantities of dissolved oxygen implied only $25 \%$ inhibition of corrosion rate, very possibly because of a certain accelerating effect of additional oxygen. A last model (model V) is observed for the two other alloys (ZAC10403, ZACS1040305) where a moderate or high amount of dissolved oxygen in the solution does not show a clear evidence of acceleration or inhibition of the corrosion rate. These two alloys have shown active and strong corrosion rates in a way that oxygen concentration has no significant effect on dissolution rate or that possibly inhibition eliminated or neutralized the accelerating effect of dissolved oxygen concentration.

3.5. Pitting Analysis. The morphology of the corrosion products formed on the surface of the AZ and ZA magnesium alloy specimens after $8 \mathrm{~h}$ of immersion in untreated $5 \% \mathrm{NaCl}$ solution saturated with $\mathrm{Mg}(\mathrm{OH})_{2}$ at $\mathrm{pH} 9$ was investigated. Following the corrosion test, the samples were submitted to slight mechanical polishing which enabled us to observe pits underneath the corrosion product with no alteration. Pitting phenomena in the aerated and deaerated solutions produced similar results and followed the same trend as that recorded in the untreated solution. Figure 4 shows the pitting formation at the corroded surface of AZ91D and ZA10403 specimens following $8 \mathrm{~h}$ of immersion in the untreated chloride solution.

For AZ91D, it appears evident that pitting corrosion resulted in a localised surface attack. This highly focused corrosion thus created cavities or pits on the surface

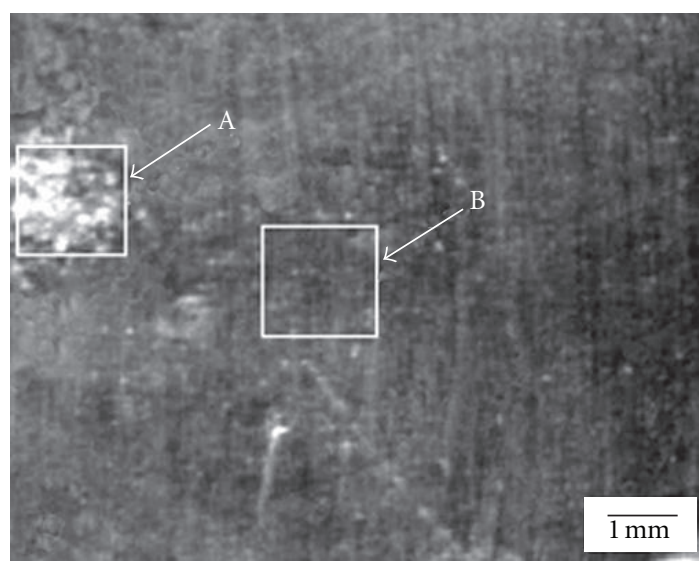

(a)

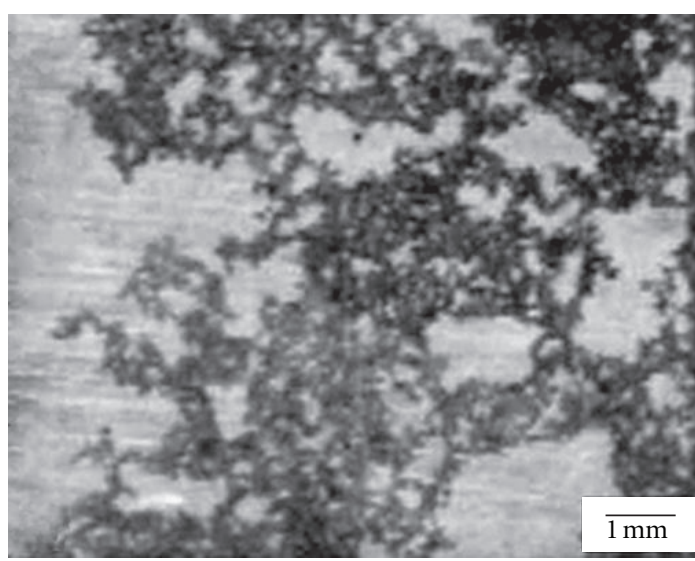

(b)

FIgure 4: Optical observation of pitting for (a) AZ91D and (b) ZA10403 after $8 \mathrm{~h}$ of immersion in untreated $5 \% \mathrm{NaCl}$ solution saturated with $\mathrm{Mg}(\mathrm{OH})_{2}$ at $\mathrm{pH} 9$ and $25^{\circ} \mathrm{C}$.

(Figure 4(a)). The size of the affected zones varied extensively, from very deep and localised to small and hollow over a large region. Pit shape also varied: narrow and deep, shallow and wide, elliptical, as well as vertical or horizontal attack sites, or subsurface cavities. For example, on alloy ZA10403, the type of corrosion pitting was wide and more uniform (Figure 4(b)).

In Figure 5, two zones (inserts A and B) of the AZ91D specimen from Figure 4(a) were further investigated by means of an AFM apparatus. Figure 5(a) shows a 3D surface analysis of the corroded zone (insert A) while Figure 5(b) illustrates an unattacked zone (insert B). The corroded region was completely different from the nonattacked area and was free from scratches. Although no specific mechanism for (1) pit nucleation or (2) pit growth has been acknowledged, the pitting process can generally be mapped by examining cell concentration phenomena. These important passive and active regions are a demonstration of the presence of dominated accelerated effect of dissolved oxygen concentration on corrosion rate as well as strong passive sites very possibly due to magnesium hydroxide and/or passive film. This model associates pit nucleation 


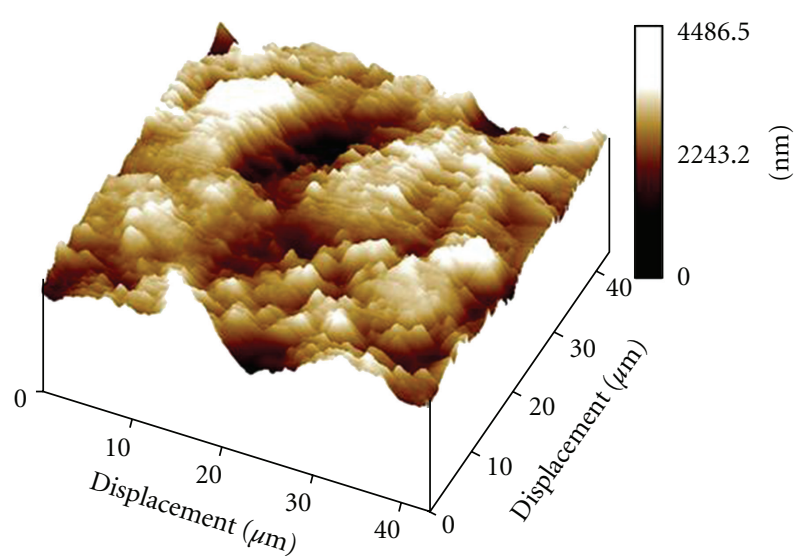

(a)

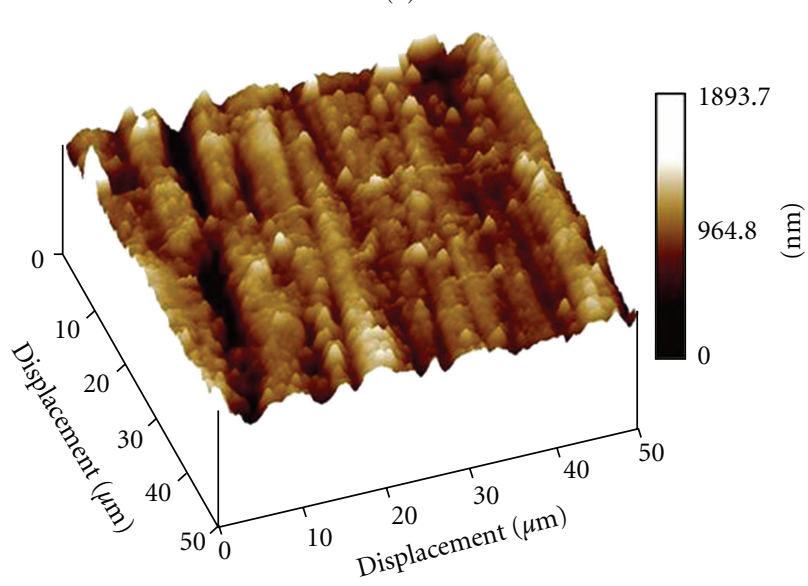

(b)

Figure 5: 3D AFM image of AZ91D showing (a) a corroded surface (Figure 4(a), insert A) and (b) an nonattacked zone (Figure 4(a), insert B) after $8 \mathrm{~h}$ of immersion in untreated $5 \% \mathrm{NaCl}$ solution saturated with $\mathrm{Mg}(\mathrm{OH})_{2}$ at $\mathrm{pH} 9$ and $25^{\circ} \mathrm{C}$.

or initiation with a localised loss of passivity in the alloy. According to one proposed mechanism, breakdown of the passive film is the result of the presence of strong complex agents in the solution (i.e., $\mathrm{Cl}^{-}$ions) interacting chemically with this film and catalytically dissolving the passive layer until the metal surface is reexposed. The formation of oriented scratches in Figure 5(b) is due simply to mechanical polishing prior to optical observation.

Figure 6 illustrates the pitting on the corroded surface of $\mathrm{AZ}$ and $\mathrm{ZA}$ alloy specimens following $8 \mathrm{~h}$ of immersion in untreated solution. Figure 6(a) presents an optical micrograph of AZ91E surface cross-section specimen showing two pits (number 1 and number 2 ) measuring $\approx 105$ and $162 \mu \mathrm{m}$ in depth, respectively. The SEM high magnification micrograph in Figure 6(b) shows a typical pit shape on AZ91E surface which resembles a deep conical crater. AZ91D surface specimen presented comparable results of pitting corrosion (Figure 6(c)). For the ZA alloys, pit depth measurement was difficult because of the uniform pit distribution and the fact that the pits were narrow and well integrated in the surface (Figure 6(d)). It can be stated at this point that pit depth was more significant in the AZ alloys than in the ZA alloys.

\section{Conclusions}

The main conclusion of this work is that the performance of magnesium alloy in alkaline chloride passive medium is not as predictable as it is in acid medium and depends on several characteristics of the studied alloy. In this context, the corrosion behaviour of two groups of magnesium alloys (AZ and ZA) was investigated in deaerated, untreated, and aerated $5 \% \mathrm{NaCl}$ solutions saturated with $\mathrm{Mg}(\mathrm{OH})_{2}$ at $\mathrm{pH} 9$ and $25^{\circ} \mathrm{C}$. The following conclusions are emphasized.

(i) Open circuit potential in untreated and aerated with respect to the deaerated solutions did not show important potential shifts. This could be explained by the complex effect of dissolved oxygen concentration in the solution (acceleration of the cathodic reaction, inhibition, formation of corrosion products, and/or passivation). Principally, no relation has been observed between the potential shift and corrosion rates as a function of dissolved oxygen in the solution.

(ii) Five mechanistic corrosion models showing the oxygen effect on corrosion rates of magnesium alloys are suggested: (model I) dominant acceleration, (model $(\mathrm{I}+\mathrm{II}))$ acceleration, inhibition and/or passivation, (model II) dominant inhibition and/or passivation, (model III) no influence on corrosion rates of oxygen saturation by bubbling as compared to atmospheric oxygen saturation, (model IV) higher corrosion rate without oxygen, and (model V) almost no influence was identified due to oxygen presence.

(iii) Corrosion rates of AZ91D and ZA104 alloys were sensitive to the presence of oxygen in alkaline medium. However, untreated and aerated solutions showed the same acceleration of corrosion rates by $50 \%$.

(iv) Despite the presence of fewer impurities in the AZ91E alloy, it recorded a higher corrosion rate than did AZ91D alloy in the deaerated medium, very possibly caused by the absence of the conditions required for passivation.

(v) ZAC10403 alloy has shown the highest corrosion rates, followed by ZACS1040305 and ZA104 alloys. Minor additions of $\mathrm{Ca}$ or $(\mathrm{Ca}+\mathrm{Sr})$ in ZAC10403 and ZACS1040305 alloys, respectively, produced a constant corrosion rate in the three corrosive solutions.

(vi) Observations of corroded surfaces in the untreated solution confirm that the pits were more localized and deeper on AZ alloys while more uniformly distributed on ZA alloys.

(vii) Pitting phenomena on AZ and ZA alloy surfaces in aerated and deaerated solutions showed similar results and followed the same trend as that recorded in untreated solution.

\section{Acknowledgments}

The authors would like to thank the Natural Sciences and Engineering Research Council of Canada (NSERC) for their 


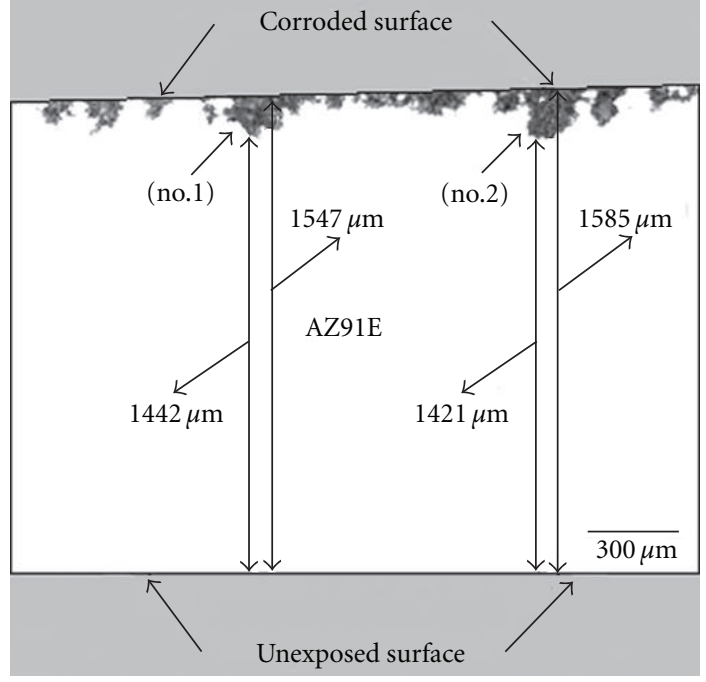

(a)

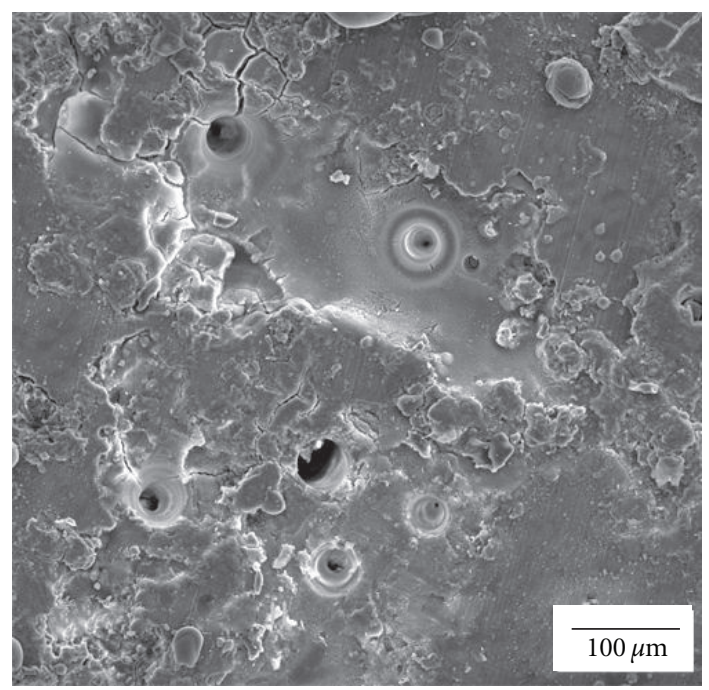

(c)

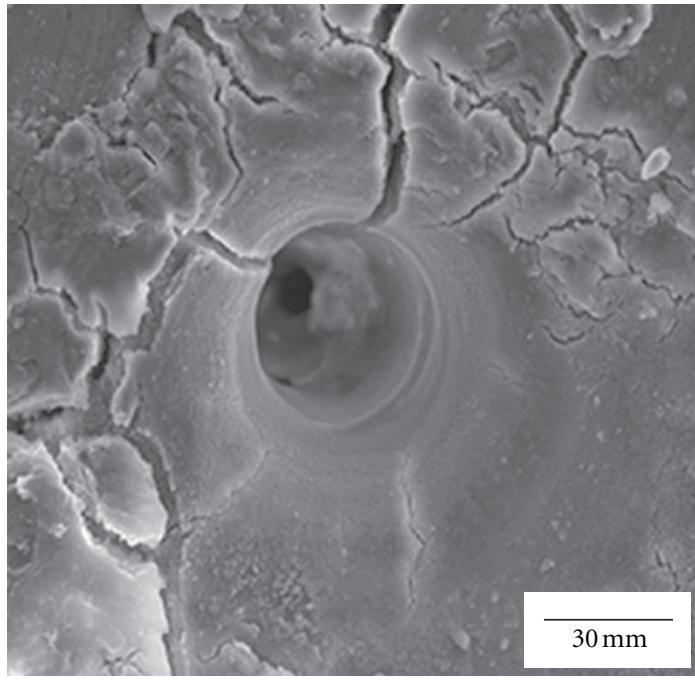

(b)

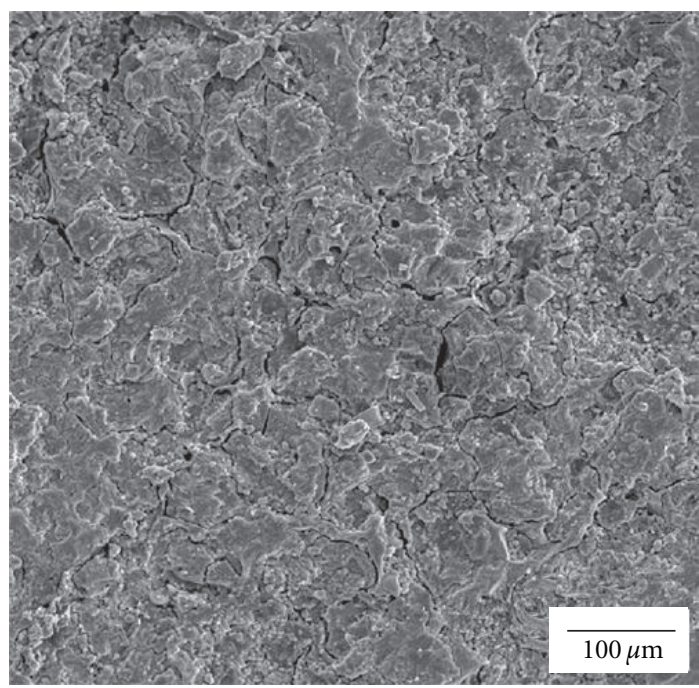

(d)

FIGURE 6: Micrographs of ((a) and (b)) optical pit depth and SEM pit shape on AZ91E surfaces, respectively, and ((c) and (d)) SEM corroded surfaces on AZ91D and ZA104, respectively, after $8 \mathrm{~h}$ of immersion in untreated $5 \% \mathrm{NaCl}$ solution saturated with $\mathrm{Mg}(\mathrm{OH})_{2}$ at $\mathrm{pH} 9$ and $25^{\circ} \mathrm{C}$.

financial support. They also express their profound gratitude to Dr. A.-M. Lafront (Université Laval), for her supervision and participation during the realisation of this work. Special thanks to the personnel of the Department of Mining, Metallurgical and Materials Engineering (Université Laval) for their professional and technical assistance.

\section{References}

[1] B. Landkof, "Magnesium applications in the electronic industries," in Proceedings of the 2nd Israeli International Conference on Magnesium Science \& Technology, E. Aghion and D. Eliezer, Eds., pp. 50-56, Magnesium Research Institute, Sdom, Israel, February 2000.

[2] D. Magers and J. Willekens, "Global outlook on the use of magnesium die-castings in automotive applications," in Proceedings of the Magnesium Alloys and their Application, B. L.
Mordike and K. U. Kainer, Eds., pp. 105-112, WerkstoffInformationsgesellschaft Gmbh, Frankfurt, Germany, 1998.

[3] K. Nisancioglu, O. Lunder, and T. K. Aune, "Corrosion mechanism of AZ91 magnesium alloy," in Proceedings of the International Magnesium Association, pp. 43-50, Detroit, Minn, USA, 1990.

[4] Z. Szklarska-Smialowska, Pitting Corrosion of Metals, NACE International, Houston, Tex, USA, 1986.

[5] B. E. Wilde and E. Williams, "On the correspondence between electrochemical and chemical accelerated pitting corrosion tests," Journal of Electrochemical Society, vol. 117, no. 6, pp. 775-779, 1970.

[6] S. Lebeau, Y. Yamamoto, and K. Sakamoto, "Thixomolding of magnesium automotive components," SAE Technical Paper 980087, International Congress and Exposition, Detroit MI, USA, 1998.

[7] I. Nakatsugawa, F. Yamada, H. Takayasu, T. Tsukeda, and K. Saito, "Corrosion behavior of thixomolded $\mathrm{Mg}$-Al alloys," in 
Proceedings of the International Symposium on Environmental Degradation of Materials and Corrosion Control in Metals, pp. 113-123, Québec, Canada, August 1999.

[8] R. Decker, R. Carnahan, R. Vining, D. Walukas, S. Lebeau, and N. Prewitt, "Thixomolding magnesium based alloys," in Proceedings of the Magnesium Alloys and Their Applications, B. L. Mordike and K. U. Kainer, Eds., pp. 545-550, Werkstoff-Informationsgesellschaft Gmbh, Frankfurt, Germany, April1998.

[9] T. Yamaguchi, T. Sukeda, and K. Saito, "Thixomoldingits features and assignments," Kikai-Gijutsu, Nikkan Kogyo Shinbun, vol. 47, no. 3, pp. 59-64, 1999.

[10] G. L. Makar and J. Kruger, "Corrosion studies of rapidly solidified magnesium alloys," Journal of the Electrochemical Society, vol. 137, no. 2, pp. 414-421, 1990.

[11] J. H. Nordlien, K. Nisancioglu, S. Ono, and N. Masuko, "Morphology and structure of water-formed oxides on ternary MgAl alloys," Journal of the Electrochemical Society, vol. 144, no. 2, pp. 461-466, 1997.

[12] G. Baril and N. Pébère, "Corrosion of pure magnesium in aerated and deaerated sodium sulphate solutions," Corrosion Science, vol. 43, no. 3, pp. 471-484, 2001.

[13] H. Alves, U. Koster, E. Aghion, and D. Eliezer, "Environmental behavior of magnesium and magnesium alloys," Materials Technology, vol. 16, no. 2, pp. 110-126, 2001.

[14] R. Ambat, N. N. Aung, and W. Zhou, "Evaluation of microstructural effects on corrosion behaviour of AZ91D magnesium alloy," Corrosion Science, vol. 42, no. 8, pp. 1433-1455, 2000.

[15] G. Song, A. Atrens, and M. Dargusch, "Influence of microstructure on the corrosion of diecast AZ91D," Corrosion Science, vol. 41, no. 2, pp. 249-273, 1998.

[16] C. Suman, "Effects of direct aging on mechanical properties and corrosion resistance of diecast magnesium alloys AZ91D and AM60B," SAE Transactions, vol. 99, no. 5, pp. 849-859, 1990.

[17] O. Lunder, M. Videm, and K. Nisancioglu, "Corrosion resistant magnesium alloys," SAE Technical Paper 950428, International Congress and Exposition, Detroit, MI, USA, 1995.

[18] G. Neite, K. Kubota, K. Higashi, and F. Hehmann, "Magnesium-based alloys," Materials Science and Technology A, vol. 8, pp. 113-213, 1996.

[19] I. A. Anyanwu, T. Honda, S. Kamado, Y. Kojima, S. Takeda, and T. Ishida, "Heat and corrosion resistance of Mg-Zn-AlCa alloys," in Proceedings of the Magnesium Alloys and Their Applications, K. U. Kainer, Ed., pp. 110-115, Wiley-VCH, Weinheim, Germany, 2006.

[20] E. Øvrelid, G. B. Floøistad, T. Rosenqvist, P. Bakke, and T. A. Engh, "The effect of Sr addition on the hydrogen solubility and hydride formation in pure $\mathrm{Mg}$ and the alloy AZ91," Scandinavian Journal of Metallurgy, vol. 27, no. 3, pp. 133-140, 1998.

[21] A. M. Lafront, M. Ö. Öteyaka, R. D. Klassen, P. R. Roberge, and E. Ghali, "Study of the corrosion of zinc and aluminium magnesium alloys by electrochemical noise (EN) and scanning reference electrode technique (SRET)," in Proceedings of the NACE International Seminar, Montréal, Canada, August 2002.

[22] M. Ö. Öteyaka, A. M. Lafront, R. Tremblay, and E. Ghali, "Pitting corrosion of some magnesium alloy by scanning reference technique (SRET)," in Proceedings of the NACE International Seminar, Montréal, Canada, August 2002.

[23] M. Ö. Öteyaka, A. M. Lafront, E. Ghali, and R. Tremblay, "Pitting corrosion potential of magnesium alloys in different corrosive media," in Proceedings of the NACE International Seminar, Montréal, Canada, August 2002.

[24] M. Ö. Öteyaka, A. M. Lafront, E. Ghali, and R. Tremblay, "Potentiodynamic study of some AZ and ZA magnesium alloys in different corrosive media," in Proceedings of the Magnesium Alloys and Their Applications, K. U. Kainer, Ed., pp. 517-523, International Magnesium Association, Wolfsburg, Germany, 2003.

[25] ASTM B93/B93M-09, "Standard specifications for magnesium alloys in ingot form for sand castings, permanent mold castings, and die castings," ASTM International, West Conshocken, Pa, USA, 2009.

[26] ASTM G5-94, "Standard reference test method for making potentiostatic and potentiodynamic anodic polarization measurements," ASTM International, West Conshocken, Pa, USA, 2004.

[27] H. H. Uhlig, D. N. Triadis, and M. Stern, "Effect of oxygen, chlorides, and calcium ion on corrosion inhibition of iron by polyphosphates," Journal of Electrochemical Society, vol. 102, no. 2, pp. 59-66, 1955.

[28] G. L. Song and A. Atrens, "Corrosion mechanisms of magnesium alloys," Advanced Engineering Materials, vol. 1, no. 1, pp. 11-33, 1999.

[29] L. L. Shreir, R. A. Jarman, and G. T. Burnstein, "Basic concepts of corrosion, oxygen reduction, corrosion in aqueous solutions," in Corrosion, vol. 1, pp. 99-105, Butterworth Heinemann, Oxford, UK, 1995.

[30] H. H. Uhlig and R. W. Revie, "Effect of dissolved oxygen," in Corrosion and Corrosion Control, Iron and Steel, pp. 91-96, John Wiley \& Sons, NY, NY, USA, 3rd edition, 1985.

[31] E. Ghali, "Magnesium performance," in Corrosion Resistance of Aluminum and Magnesium Alloys, Understanding, Performance, and Testing, pp. 338-343, John Wiley \& Sons, Hoboken, NJ, USA, 2010. 

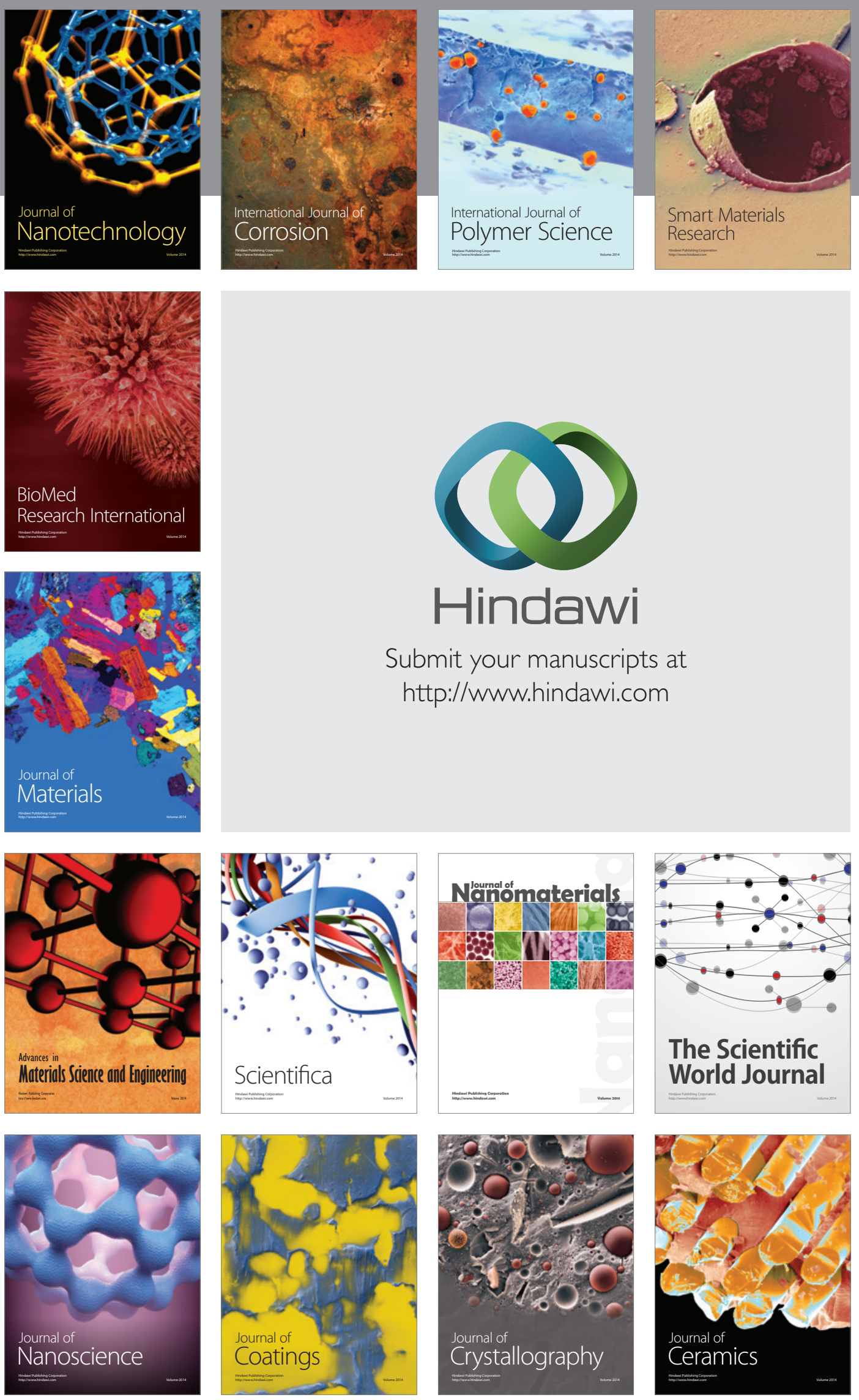

The Scientific World Journal

Submit your manuscripts at

http://www.hindawi.com

\section{World Journal}

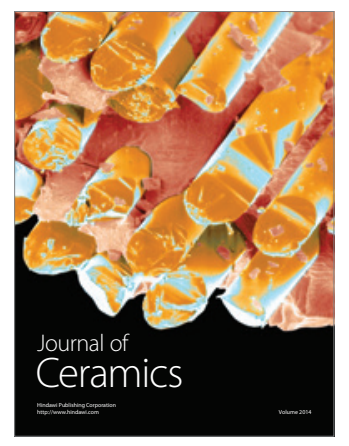

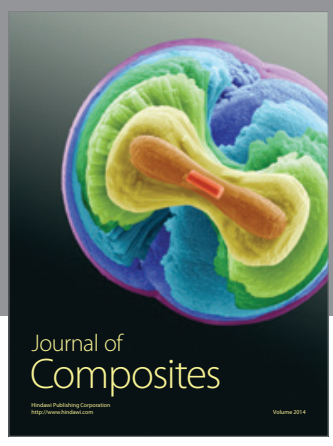
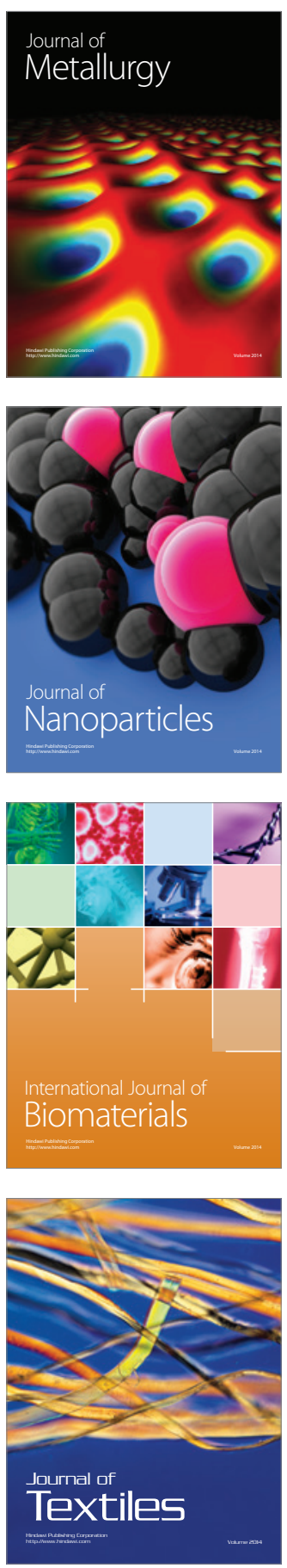